\title{
The Structure of the Lithosphere in Diamond-Bearing Kimberlite Areas. The Siberian Platform
}

\author{
Milshtein, E.D. ${ }^{1}$, Erinchek, Yu.M. ${ }^{1}$, Egorkin, A.V. ${ }^{2}$, and Parasotka, B.S. ${ }^{3}$
}

1. Geological Research Institute (VSEGEI), St.Petersburg 199106, Russia

2. Center of Regional Geophysical and Geological Research (Center GEON), Moscow 119034, Russia

3. «Almazy Rossii-Sakha» Co. Ltd, td, Mirny 678170, Russia

\section{Introduction}

The authors support idea that generation and intrusion of diamond-bearing kimberlites were stimulated by processes in mantle. This processes affected the lithosphere as well. Some peculiar results of this process are represented by formation of specific earth crust and upper mantle structure discussed here on the example of well-studied Siberian platform.

The thirty four kimberlite fields of different diamond concentration are known to be located in various parts of the Siberian Platform. Five of them are rich of diamonds. These fields are: Mirny (№ 2), Sredne-Markha (Nakyn) (№. 3), Alakit (№. 4), Daldyn (№. 5) and Muna (№. 6). They are the Middle Paleozoic and are located compactly in the center of the platform. The main task of this paper is to discuss specific features of the Middle Paleozoic tectonic-magmatic stage and to elaborate setting of the diamond-bearing areas in the deep structure of the Siberian platform.

The results discussed below are based on the analysis of a set of original maps showing specific features of the platform deep structure. This set was compiled by authors on the basis of published data on deep seismic sounding of Center GEON, Yakutian Institute of Geological Sciences, Botuobian expedition, Irkutsk Geophysica (Egorkin et al., 1988; Suvorov, 1993) and on magnetotelluric sounding executed by VostSNIIGIMS and the numerous geology-geophysical data.

\section{Geological setting}

All mentioned diamond-bearing kimberlite fields are located on the south flank of the Anabar anticlise at its junction with Tunguss and Vilyui syneclises (Kimberlites of Yakutia, 1995). Thickness of the sedimentary cover in the area is $1,9-3 \mathrm{~km}$ that is significantly less than in adjacent areas. Archean metamorphic granite-gneiss rocks older than $2.5 \mathrm{Ga}$ compose crystalline basement of this territory.

\section{Deep structure}

Based on the radiometric data of the basement as well as the parameters of the deep structure and patterns of geophysical fields we outlined the territory of diamond-bearing kimberlites as an independent Mirny-Udachney Craton. The Craton is characterized by abnormally high thickness of the crystalline crust $(40-47 \mathrm{~km}$ ), thick lithosphere (over $200 \mathrm{~km}$ ) and low heat flow-less than $30 \mathrm{mVt} / \mathrm{m}^{2}$ (Erinchek et. al., 1997). The crystalline crust has specific layering: thin upper layer (10$14 \mathrm{~km}$ ), thick intermediate layer (up to $20 \mathrm{~km}$ ) and moderate thickness of the lower layer (14-18 $\mathrm{km}$ ), abnormally high ratio between thickness of the low- and intermediate layer and total thickness of the crystalline crust called here as «basicity coefficient» $(\beta=0.7-0.75)$; relatively high (up to abnormally high) and sharply differentiated velocities at Moho $(8.2-8.8 \mathrm{~km} / \mathrm{s})$.

The Viluyi syneclise-post-rift structure formed above Middle Paleozoic Patom-Viluyi rift valley is situated to the south-east of Mirny-Udachney Craton. The deep parameters of this area are 
commonly typical for Mesozoic and recent rift valleys. They include: abrupt decrease in thickness of the crystalline crust (26-36 km) and its upper layer (4-12 km), thin asthenosphere (not more than $120 \mathrm{~km}$ ), abnormally high «basicity coefficient» $(\beta=0.7-0.95)$, high values (more than $40 \mathrm{mVt} / \mathrm{m}^{2}$ ) of the heat flow (Duchkov and Sokolova, 1997). The relief elements of Moho discontinuity have differentiated nature with linear forms being predominant.

To the west of Mirny-Udachney Craton there is the Tunguss syneclise. The parameters of its deep structure are intermediate between two mentioned structures. The thickness of crystalline crust is nearly $36-42 \mathrm{~km}$, thickness of lithosphere is $120-150 \mathrm{~km}$, heat flow ranges from 30 to $50 \mathrm{mVt} / \mathrm{m}^{2}$. This territory has a differ type of the crust layering comparing with two discussed above areas, and, as the result, it has low «basicity coefficient» $(\beta=0.5-0.6)$.

\section{Middle Paleozoic stage of the evolution}

At this stage of the evolution (time of diamond-bearing kimberlite manifestation) recent Viluyi syneclise was represented by Patom-Viluyi rift valley (Masaitis et. al., 1975). Mirny-Udachney Craton represented its adjoining uplift. The line of high-amplitude grabens separated by horsts was formed in the Patom-Viluyi rift valley. Here the Middle Paleozoic rift complex represented by De-

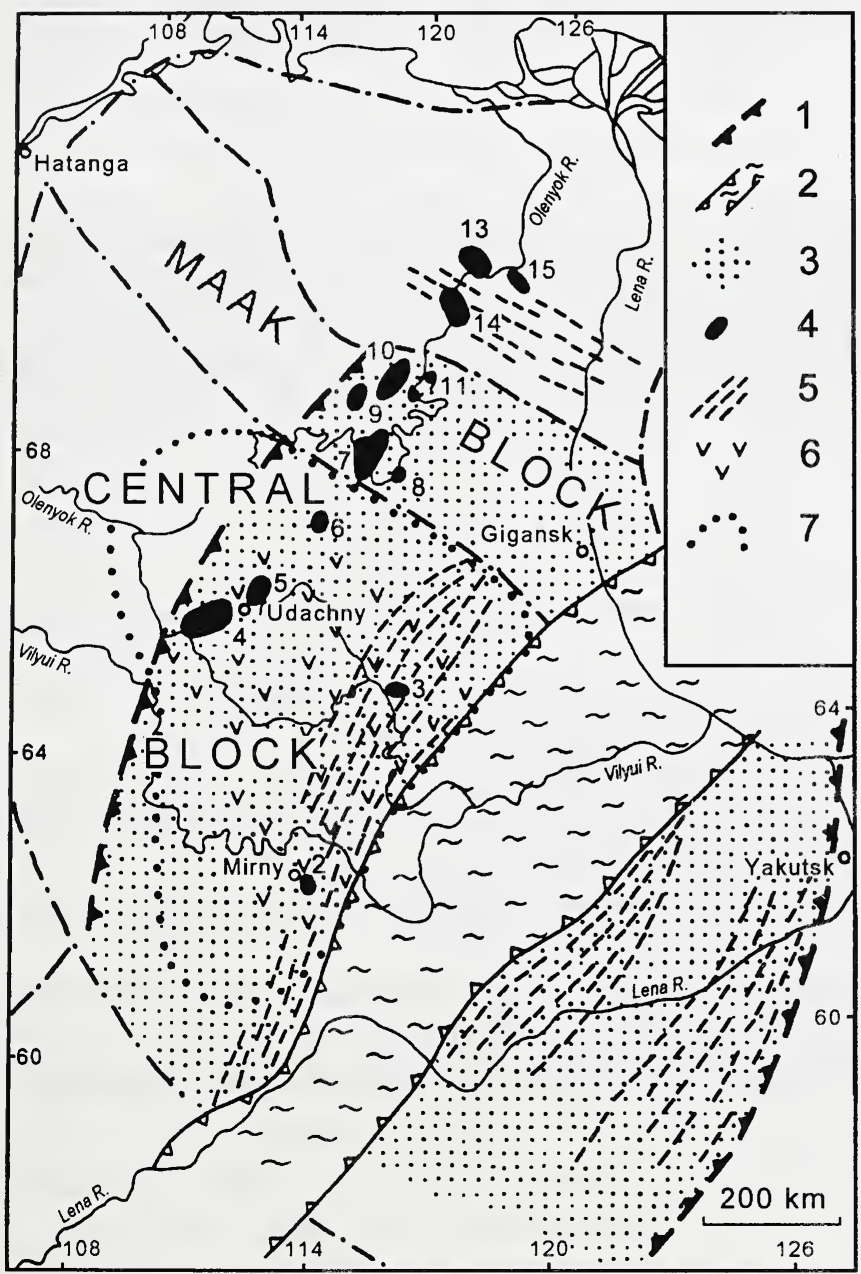
vonian-Early Carboniferous volcanic-sedimentary succession is up to $6 \mathrm{~km}$ thick. Total length of the structure is $900 \mathrm{~km}$ while the maximum width is about $300 \mathrm{~km}$. Middle Paleozoic magmatites are widely represented in the flank of Anabar anticlise (in Mirny-Udachney Craton in particular) as well as in grabens of Patom-Viluyi rift valley.

\section{Discussion}

Thus, during Middle Paleozoic the examined part of a platform was involved in intensive intracontinental rifting that led to formation of the rift valley (system of grabens) in the ax-

Figure. Tectonic position of Middle Paleozoic kimberlites in the Siberian platform.

1-3 - Sredinno-Sibirskaya Middle Paleozoic Rift System: 1 - boundary, 2 - trough zone, 3 - marginal zones; 4-6 - the magmatites of marginal zones of Rift System: $4-$ high-diamond-bearing (№ 2-6) and diamondless (№ 7-15) kimberlite fields; 5 - mafic dyke belts, 6mafic sills; 7 - Mirny-Udachney Craton. 
ial part and in manifestation of wide magmatites areal, in axial part as well as in the adjoining uplifts. Middle Paleozoic magmatic rocks have distinct lateral zonality. Mafic volcanics manifested within the axial part, intrusive sills recorded in both trough and marginal (uplifts) parts; mafic dykes and pipes and also kimberlite bodies are manifested exclusively within adjoining uplifts (in Craton as well). Dykes and sills are recorded at a distance of up to $300 \mathrm{~km}$ from the trough edge.

The area involved in rifting and contained magmatites associated with the rift, we identify as united Middle Paleozoic Sredinno-Sibirskaya Rift System (Erinchek et. al., 1997). It includes axial trough zone (Patom-Viluyi aulacogen by Masaitis et. al., 1975) and two extensive adjoining marginal areas (zones): north-west and south-east. The deep structure of the axial zone is dominated by Middle Paleozoic rifting. The structure of marginal areas is mainly determined by the evolution of these territories during the Precambrian. So, in north-west marginal areas two Precambrian block (Mirny-Udachney Craton and Maak block) with different type of the Precambrian evolution (thus, with differ characteristics of deep structure) were involved in rifting. The influence of rifting in the peripheral zones was significantly less than in axial one. For this reason it is rather difficult to mark the elements of deep structure related only with the Middle Paleozoic rifting. However, we would like to point to similarity of the crystalline crust layering between the Mirny-Udachney Craton and the rift trough zone (Patom-Viluyi aulacogen).

The diamond-bearing kimberlites and most complete association of mafic magmatites realized in Mirny-Udachney Craton. The diamondless kimberlites realized in Maak block, mafic magmatites are unknown here.

\section{Conclusion}

We believe that two main factors are responsible for manifestation of high-diamondiferous kimberlites in the central part of Siberia platform. They are the mantle magma-generating structure-intracontinental Middle Paleozoic Sredinno-Sibirskaya Rift System-and a specific block-MirnyUdachney Craton-within it. The latter is characterized by thick lithosphere and crystalline crust with certain type of layering. This block of ancient formation did not endure destruction during the Phanerozoic.

\section{References}

Duchkov, A.D., and Sokolova, L.S., 1997, Thermal structure of lithosphere of the Siberia Platform: Geologiya i Geofizika, 2, p. 494-503

Egorkin, A.V., Zuganov, S.K., Pavlenckova, N.I., and Chernyshov, N.M., 1988, Results of lithosphere structure research on the sections of Siberia: Geologiya i Geofizika, 5, p. 120-128.

Erinchek, Yu.M., Milshtein, E.D., Kolesnic, N.N., and Saltykov, O.G., 1997, The deep structure of diamondiferous kimberlite areas of the Siberian platform: Mineral Deposits: Research and Exploration Where do They Meet? A.A.Balkema, Rotterdam, Brookfield, p. 763-766

Kimberlites of Yakutia, 1995, Sixth International Kimberlite Conference. Field Guide Book. Novosibirsk $108 \mathrm{p}$.

Masaitis, V.L., Mikhailov, M.V., and Selivanovskaya, T.V., 1975, Volcanism and tectonics of the Patom-Vilyuy Middle Paleozoic aulacogen. Moscow: Nedra, 182 p.

Suvorov, V.D., 1993, The deep seismic research in Yakutia kimberlite province. Novosibirsk: Nauka, 136 p. 